\title{
Epidemiological study of asymptomatic inflammatory bowel disease: the identification of cases during a screening programme for colorectal cancer
}

\author{
J F MAYBERRY, K C BALlantyne, J D HARDCASTle, C MANGHAM, \\ AND G PYE
}

From the Dept of Surgery, Queens Medical Centre, University Hospital of Nottingham, Nottingham

\begin{abstract}
SUMMARY An asymptomatic population of 37000 people in the Nottingham area were offered faecal occult blood tests in a screening study for colorectal cancer. Seventeen thousand nine hundred and thirty people completed the tests and 481 individuals with positive tests underwent full investigation of the colon. Eight people with previously undiagnosed inflammatory bowel disease were identified. In five cases there was total ulcerative colitis; in one a proctitis and in two Crohn's disease. Two further patients with ulcerative colitis were identified; they had been lost to follow up for 25 and 45 years respectively. The combined prevalence of inflammatory bowel disease was $56 / 10^{5}$ and it is likely that current studies of the epidemiology of these conditions may underestimate the true prevalence by between $27 \%$ and $38 \%$.
\end{abstract}

All epidemiological studies are bedevilled by the problem of undetected cases and this is especially so in inflammatory bowel disease, where all previous studies have been based on patients diagnosed in hospital. In Nottingham the existence of a screening programme for colorectal cancer provided an opportunity for apparently asymptomatic cases of inflammatory bowel disease to be identified and their prevalence in the population to be assessed.

\section{Method}

\section{PATIENTS}

Between 1983 and 198737000 patients aged between 50 and 75 years in 39 general practices within the Nottingham area were offered faecal occult blood testing (FOBT) as screening for colorectal cancer. General practitioners were asked to exclude patients with known bowel disease including ulcerative colitis, and Crohn's disease. Screening was performed with either a chemical guaiac test (Haemoccult) or an immunological test for human haemoglobin (Feca-EIA) over three or six days. Individuals with a positive test were investigated by

Address for correspondence: Dr John Mayberry, City Hospital, Hucknall Road, Nottingham NG5 1PB.

Accepted for publication 30 September 1988. either colonoscopy or flexible sigmoidoscopy and double contrast barium enema.

\section{Results}

Of the 37000 patients offered screening, 17930 accepted and 481 had a positive FOB test. Investigation of these patients revealed 15 in whom gastrointestinal bleeding could be attributed to inflammatory bowel disease. Five patients had ulcerative proctocolitis which had been diagnosed within the past 10 years and were still under active hospital follow up and as such should have been excluded from the study. In two other patients (Table 1) the diagnosis of ulcerative colitis had been made 25 and 45 years earlier. Neither patient had been followed up, although they had evidence of colitis on endoscopic examination of the colon.

Six patients, four men and two women, were found to have ulcerative colitis (Table 2) and in five of the cases histological abnormalities were found throughout the colon. Two further patients (Table 2) had Crohn's disease. Two patients admitted to loose bowel motions, the remainder were completely asymptomatic. None of the patients had sought medical advice because of abdominal pain, diarrhoea or rectal bleeding. 
Table 1 Patients with inflammatory bowel disease lost to medical follow up

\begin{tabular}{|c|c|c|c|c|c|c|c|}
\hline Patient & Age & Sex & Symptoms & Diagnosis & Investigations & $\begin{array}{l}\text { Extent of } \\
\text { colitis }\end{array}$ & Histology \\
\hline JS & 56 & $\mathrm{~F}$ & None & $\begin{array}{l}\text { Ulcerative colitis: } 25 \text { years ago had } \\
\text { one episode }\end{array}$ & $\begin{array}{l}\text { Double contrast barium enema } \\
\text { and colonoscopy }\end{array}$ & Total & $\begin{array}{l}\text { Severe active colitis with acute } \\
\text { or chronic changes }\end{array}$ \\
\hline HS & 75 & M & None & $\begin{array}{l}\text { Ulcerative colitis: } 45 \text { years ago had } \\
\text { one episode }\end{array}$ & $\begin{array}{l}\text { Double contrast barium enema } \\
\text { and colonoscopy }\end{array}$ & Total & Chronic non specific changes \\
\hline
\end{tabular}

The prevalence of these two cases who were lost to follow up for more than 20 years was $11 \cdot 2 / 10^{\circ}\left(95 \%\right.$ confidence interval $\left.0-44 \cdot 6 / 10^{\circ}\right)$.

Table 2 Undiagnosed inflammatory bowel disease identified during a survey of colorectal bleeding

\begin{tabular}{|c|c|c|c|c|c|c|c|}
\hline Patient & Age & Sex & Symptoms & Diagnosis & Investigations & Extent of colitis & Histology \\
\hline $1 \mathrm{JP}$ & 70 & $\mathbf{M}$ & None & Ulcerative colitis & Colonoscopy & Total & Severe active colitis \\
\hline $2 \mathrm{AA}$ & 56 & $\mathbf{M}$ & $\begin{array}{l}\text { Occasional diarrhoea } \\
\text { for } 2 \text { years }\end{array}$ & Ulcerative colitis & Colonoscopy & Total & Moderate active colitis \\
\hline $3 \mathrm{BR}$ & 53 & $\mathbf{M}$ & None & Ulcerative colitis & Colonoscopy & Total & $\begin{array}{l}\text { Moderately severe acute } \\
\text { on chronic colitis }\end{array}$ \\
\hline $4 \mathrm{CS}$ & 65 & $\mathbf{M}$ & None & Ulcerative colitis & Colonoscopy & $\begin{array}{l}\text { Endoscopy changes limited } \\
\text { to rectum histological } \\
\text { abnormalities throughout } \\
\text { colon }\end{array}$ & $\begin{array}{l}\text { Mild active colitis, most } \\
\text { severe in rectum }\end{array}$ \\
\hline $5 \mathrm{HM}$ & 75 & $\mathrm{~F}$ & None & Ulcerative colitis & Colonoscopy & Rectum and sigmoid colon & Mild active colitis \\
\hline $6 \mathrm{IF}$ & 67 & $\mathrm{~F}$ & Some loose motions & Ulcerative colitis & Colonoscopy & Rectum & $\begin{array}{l}\text { Severe acute on chronic } \\
\text { proctitis }\end{array}$ \\
\hline $7 \mathrm{DF}$ & 61 & $\mathrm{~F}$ & None & Crohn's disease & $\begin{array}{l}\text { Colonoscopy, barium } \\
\text { enema and laparotomy }\end{array}$ & Ileocaecal & Crohn's disease \\
\hline $8 \mathrm{JP}$ & 60 & $\mathrm{~F}$ & None & Crohn's disease & $\begin{array}{l}\text { Colonoscopy, barium } \\
\text { enema, gastroscopy } \\
\text { and laparotomy }\end{array}$ & $\begin{array}{l}\text { Two localised ileal } \\
\text { strictures }\end{array}$ & Crohn's disease \\
\hline
\end{tabular}

Eight patients with inflammatory bowel disease were identified during a screening programme for colorectal cancer.

The prevalence of previously undiagnosed ulcerative colitis in this population aged between 50 and 75 years was at least $33 \cdot 5 / 10^{5}$ (Table 3 ). It is likely that this is an underestimate as it is improbable that all cases were detected by the FOB test. If the two patients lost to follow up were included as well as the asymptomatic cases the prevalence rose to $44 \cdot 6 / 10^{5}$ (95\% confidence interval $22 \cdot 3-89 \cdot 2)$. The prevalence of asymptomatic Crohn's disease was $11 \cdot 2 / 10^{5}$, a third of that reported for symptomatic Crohn's disease from other centres.

\section{Discussion}

The true prevalence of any disease state is difficult to determine. This is the first study to identify previously undiagnosed asymptomatic cases of inflammatory bowel disease in the community. This has only been possible because of the existence of a large population screening study for the detection of colorectal neoplasia using FOBT. Most studies suggest that the combined prevalence of symptomatic ulcerative colitis and Crohn's disease lies between $90 / 10^{\varsigma}$ and $150 / 10^{\varsigma}$. In 1980 Devlin et al in a study from North Tees, England reported the com-
Table 3 Prevalence of inflammatory bowel disease in an asymptomatic population aged 50-74

\begin{tabular}{llll}
\hline & $\begin{array}{l}\text { Cases } \\
(n)\end{array}$ & Population & $\begin{array}{l}\text { Prevalence (cases/10 } \\
\text { population and 95\% } \\
\text { confidence interval) }\end{array}$ \\
\hline Ulcerative colitis & 6 & 17922 & $\begin{array}{l}33 \cdot 5(11 \cdot 2-78 \cdot 1) \\
\text { Crohn's disease }\end{array}$ \\
2 & 17922 & $11 \cdot 2(0-44 \cdot 6)$ \\
\hline
\end{tabular}

Eight previously undiagnosed patients with inflammatory bowel disease were identified during a screening programme for colorectal cancer.

Table 4 Reported prevalence of symptomatic inflammatory bowel disease

\begin{tabular}{lll}
\hline & \multicolumn{2}{c}{ Prevalence (cases/10'population) } \\
\cline { 2 - 3 } Study centre & Crohn's disease & Ulcerative colitis \\
\hline Oxford $^{*}$ & 9 & 80 \\
North Tees' $_{\text {Cardiff' }}^{4}$ & 35 & 99 \\
High Wycombe $^{\prime}$ & 56 & 70 \\
Copenhagen County & 32 & 117 \\
\hline
\end{tabular}

The prevalence of symptomatic inflammatory bowel disease as reported in Britain and Scandinavia. 
bined prevalence was $134 / 10^{5}$. Ulcerative colitis in general has a prevalence about twice that of Crohn's disease $^{2}$ and in this study of asymptomatic patients the rate was similar at about three to one. The overall prevalence of symptomatic ulcerative colitis in Britain has been reported as between 70 and $99 / 10$ (Table 4 ) compared with $33 \cdot 5 / 10^{5}$ asymptomatic cases reported in this study. The prevalence of Crohn's disease is between 35 and 56/10' (Table 4) and data from Cardiff suggest that the prevalence in those aged 50 to 75 years is about $48 / 10^{\circ}$. The prevalence of asymptomatic Crohn's disease in this study was $11.2 /$ $10^{5}$. It seems likely that studies which are based on symptomatic patients diagnosed in hospital may underestimate the true prevalence of inflammatory bowel disease by between $27 \%$ and $38 \%$. Such findings are of considerable importance to our understanding of the epidemiology of these diseases.

It is unlikely that the increase in incidence that has recently been reported in many countries ${ }^{2 x}$ is the result of increased detection of apparently asymptomatic patients. It is interesting that even on direct questioning most of the patients identified in this study denied symptoms of inflammatory bowel disease, despite the extent of their disease. The only two patients who admitted to any gastrointestinal symptoms considered them minimal and of no consequence.

In seven of the eight patients with ulcerative colitis there was total involvement of the colon. This identification of a high proportion of patients with total colitis and only one case of proctitis may be a reflection of the technique used to detect blood loss rather than a true reflection of the pattern of asymptomatic disease in the community. The modified guaiac test relies on the presence of haemolysed blood in faeces to produce a positive result. Previous studies using this technique have suggested that its ability to detect bleeding rectal cancers is less than colonic cancers. Blood shed into the rectum may be insufficiently haemolysed, less uniformly mixed with faeces and so produce a false negative result." This could explain our failure to identify more than one patient with proctitis.

This study highlights concern about the accuracy and completeness of case detection of inflammatory bowel disease. The existence of unrecognised cases of inflammatory bowel disease especially ulcerative colitis is of particular concern in view of the premalignant nature of this disease. It suggests that further study should be directed towards the early identification of such patients.

\section{References}

1 Devlin HB, Datta D, Dellipiani AW. The incidence and prevalence of inflammatory bowel disease in North Tees Health District. World J Surg 1980; 4: 183-93.

2 Mayberry JF. Some aspects of the epidemiology of ulcerative colitis. Gut 1985; 26: 968-74.

3 Evans JG, Acheson ED. An epidemiological study of ulcerative colitis and regional enteritis in the Oxford area. Gut 1965: 6: 311-24.

4 Mayberry JF, Rhodes J, Newcombe RG. Familial prevalence of inflammatory bowel disease in relatives of patients with Crohn's disease. Br Med J 1980; 1: 84

5 Jones HW. Grogono J, Hoare AM. An audit of ulcerative colitis in a district general hospital [Abstract]. Gut 1985; 26: A 1123.

6 Binder V. Both H. Hansen PK. Hendriksen C. Kreiner S, Torp-Pedersen K. Incidence and prevalence of ulcerative colitis and Crohn's discase in the County of Copenhagen 1962-1978. Gastroenterology 1982: 83: 563-8.

7 Mayberry JF, Rhodes J, Hughes LE. Incidence of Crohn's disease in Cardiff between 1934 and 1977. Gut 1979; 20: 602-8.

8 Mayberry JF, Rhodes J. Epidemiological aspects of Crohn's disease: a review of the literature. Gut 1984; 25: 886-99.

9 Farrands PA, Hardcastle JD. Accuracy of occult blood tests over a six day period. Clin Oncol 1983: 9: 217-25. 